\title{
Profile of the Implementation of Discovey Learning Model in Science Learning
}

\author{
Mahyuddin Syaifulloh ${ }^{1}$, Sifak Indana ${ }^{2}$, Rudiana Agustini $^{3}$ \\ 1,2,3State University of Surabaya, Surabaya, Indonesia
}

\begin{tabular}{|c|c|}
\hline 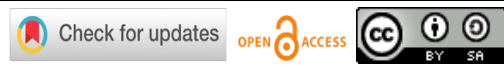 & DOI : https://doi.org/10.46245/ijorer.v3i1.187 \\
\hline Sections Info & ABSTRACT \\
\hline Article history: & \multirow{12}{*}{$\begin{array}{l}\text { Research was conducted to describe and analyze the implementation of } \\
\text { discovery learning model of science learning in Indonesia. This research } \\
\text { method uses qualitative methods with using secondary data. The sample in } \\
\text { this research is } 30 \text { articles published in international and national journals } \\
\text { Based on the analysis of } 30 \text { articles on science learning using discovery } \\
\text { learning model in Indonesia, it can be seen that the discovery learning mode } \\
\text { has a positive impact on student learning outcomes, it can improve students } \\
\text { critical thinking skills, students' science process skills, students' scientific } \\
\text { literacy, aspects of problem solving skills, and also students' understanding of } \\
\text { concepts. there are also several disadvantages of the discovery learning model } \\
\text { there are; it will be optimal if it combine with media or other methods, } \\
\text { students will be confused if they do not get the instruction from the teacher } \\
\text { and it require a lot of preparation and learning duration. Based on the } \\
\text { literature review of the implementation of the discovery learning model in } \\
\text { 2012-2021 that has been carried out, it can be concluded that the discovery } \\
\text { learning model has a positive impact on science learning. }\end{array}$} \\
\hline Submitted: December 27, 2021 & \\
\hline Final Revised: January 6, 2022 & \\
\hline Accepted: January 7, 2022 & \\
\hline Published: January 31, 2022 & \\
\hline Keywords: & \\
\hline Critical thinking & \\
\hline Discovery learning & \\
\hline Problem solving & \\
\hline Science process skills & \\
\hline Scientific literacy & \\
\hline & \\
\hline
\end{tabular}

\section{INTRODUCTION}

The essence of science learning lies in the scientific process (scientific method), the main point is that students do not just memorize concepts but students apply the scientific process in finding concepts. After students are able to apply the scientific process, it is hoped that students can find the answers of the daily natural phenomena. This is in accordance with the 2013 curriculum, science learning which was developed with a scientific approach, which emphasizes the scientific process. Yusuf \& Wulan (2015) defined Natural Science is a science that is closely related to how to find out about nature systematically, so that science is not just mastering a whole of knowledge in the form of facts, consepts, or principles, but it is also a process of discovery. Therefore, it is hoped that science learning use the scientific process, it can develop students' thinking.

Teachers need to design and prepare appropriate learning processes so that students can apply the scientific process. The learning process that involves teachers and students is designed using a learning model. The learning model as a learning stage structure serves as a systematic procedural conceptual framework to provide a learning experience to students, in accordance with the objectives to be achieved (Chusni et al., 2021). According to Chusni et al. (2021) Science learning use a scientific process must include the investigative stages, and it can be found in the discovery learning model. The discovery learning model is defined as a learning process that involves students directly, so that they can use mental processes to find concepts through a series of data or information obtained through observation or experiments (Serefina \& Luthfi, 2020). So students acquire knowledge that they through self-discovery. 
The discovery learning model has five syntaxes, there are orientation, hypothesis generation, hypothesis testing, conclusion drawing and regulation (Serefina \& Luthfi, 2020). At the orientation stage, students are asked to develop an initial understanding by involving the information and knowledge they have previously acquired. At the stage of generating a hypothesis, students are asked to develop a hypothesis from the initial problem. At the stage of testing the hypothesis, students are asked to plan and experiment to test the hypothesis. At the conclusion and regulation stage, students are asked to review the test results and relate them to the previous hypothesis, then make a final conclusion.

Discovery learning has several advantages, such as 1) the acquiring knowledge is durable, long-lasting and easier to remember; 2) the results of discovery learning have a better transfer effect, in other words the concepts and principles that students have are easier to apply to the new situations; 3) comprehensive discovery learning improves students' reasoning and free-thinking abilities; 4) specifically, discovery learning trains students' cognitive abilities to find and solve problems without another help from the other; 5) discovery learning arouses students' curiosity, motivates them to work continuously until they find answers; and 6) discovery learning trains students to analyze and manipulate information, not just accept it (Wicaksono et al., 2021). From the explanation above, it can be seen that the discovery learning model is recommended in science learning, so in this study the author will analyze the application of the discovery learning model in science learning.

\section{RESEARCH METHOD \\ General Background}

Research is a scientific activity to obtain the true knowledge about a problem, the true knowledge is obtained from the scientific method, the knowledge which is generated from research can be in the form of facts, concepts, generalizations, and theories (Kusumastuti \& Khoiron, 2019). This research uses a meta-analysis method with a literature review. This research is descriptive qualitative, this method is applied to describe how the implementation of the discovery learning model in science at the elementary and high school levels in Indonesia in 2012-2021.

\section{Participants}

In this research, the subject of study is the writer, who will analyze previous research which is related to the implementation of the discovery learning model in science learning at the elementary and high school levels in Indonesia in 2012-2021. The sample in this research is 30 articles published in international and national journals.

\section{Instrument and Procedures}

This research uses a Library Research approach. Document or text studies are reserach that focuses on the analysis or interpretation of written materials, the materials studied can be in the form of textbooks, newspaper, magazines, films, diaries, literary texts, articles, and so on (Sugiarto, 2015). In this study, data were collected from the relevant research, the discovery learning model in science studying in primary and secondary schools in Indonesia from various articles that support the problems of this research. The purpose of using this literature study method is to obtain the new knowledge which can be accepted and analyzed more deeply by researchers to explain the 
sustainability of the discovery learning model in science learning in primary and secondary schools in Indonesia in 2012-2021.

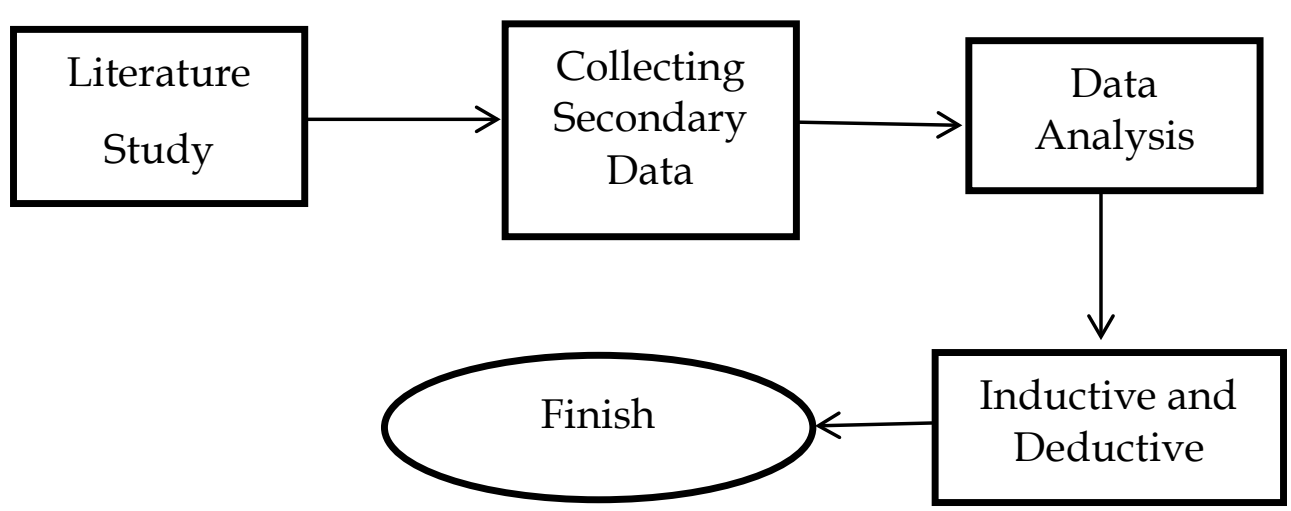

Figure 1. The flowchart of research profile of the implementation of the discovery learning model in science subjects in elementary and middle schools in Indonesia.

\section{Data Analysis}

Qualitative descriptive data analysis in this study uses secondary data analysis which is the data is already available and can be obtained by researchers by reading, watching and also listening. This data usually comes from primary data that has been processed by previous researchers (Kusumastuti \& Khoiron, 2019). The description, this research uses data sources from previous scientific works related to research discussions which are re-analyzed to solve the problems studied with data sources.

\section{RESULTS AND DISCUSSION}

Table 1. Literature study on the science studying implementation with discovery learning model in indonesia in 2012-2021.

\begin{tabular}{|c|c|c|c|}
\hline $\begin{array}{c}\text { Authors } \\
\text { (years) }\end{array}$ & $\begin{array}{c}\text { Sample } \\
\text { characteristics }\end{array}$ & Research design & The finding \\
\hline $\begin{array}{l}\text { (Ristanto et al., } \\
\text { 2021) }\end{array}$ & $\begin{array}{l}\text { The research } \\
\text { subjects were } 66 \\
\text { students in class X } \\
\text { natural science } \\
\text { State Senior High } \\
\text { School } 89 \text { Jakarta } \\
\text { in the 2018-2019 } \\
\text { school year }\end{array}$ & $\begin{array}{l}\text { - The type of research } \\
\text { is pre-experimental } \\
\text { design. } \\
\text { - Using Model } \\
\text { Guided Discovery } \\
\text { Learning-Argument } \\
\text { Mapping (GDL-AM) } \\
\text { - The research design } \\
\text { was a quasi- } \\
\text { experimental and } \\
\text { pretest-posttest } \\
\text { control grub design. } \\
\text { The research method } \\
\text { uses quantitative } \\
\text { descriptive analysis. }\end{array}$ & $\begin{array}{l}\text { There is an effect of } \\
\text { Guided Discovery } \\
\text { learning by mapping } \\
\text { arguments on critical } \\
\text { thinking skills towards } \\
\text { environment changes of } \\
\text { high school students } \\
\text { - Student responses } \\
\text { showed that Guided } \\
\text { Discovery Learning- } \\
\text { Argument Mapping } \\
\text { (GDL-AM) was able to } \\
\text { increase their curiosity } \\
\text { and interest for learning } \\
\text { about environmental } \\
\text { changes. } \\
\text { The highest critical } \\
\text { thinking skills showed in } \\
\text { the clarification aspect. }\end{array}$ \\
\hline
\end{tabular}




\begin{tabular}{|c|c|c|c|}
\hline $\begin{array}{c}\text { Authors } \\
\text { (years) }\end{array}$ & $\begin{array}{c}\text { Sample } \\
\text { characteristics }\end{array}$ & Research design & The finding \\
\hline $\begin{array}{l}\text { (Serevina \& } \\
\text { Luthfi, 2021) }\end{array}$ & $\begin{array}{l}\text { The research } \\
\text { subjects were } 35 \\
\text { students of class X } \\
\text { SMK Negeri } 53 \\
\text { Jakarta }\end{array}$ & $\begin{array}{l}\text { - The types of } \\
\text { Research } \\
\text { Development of on- } \\
\text { line discovery } \\
\text { learning model } \\
\text { science tools. } \\
\text { - Research using the } \\
\text { Addie model } \\
\text { (analysis, design, } \\
\text { development, } \\
\text { implementation, and } \\
\text { evaluation). } \\
\text { The results of the } \\
\text { study were analyzed } \\
\text { using quantitative } \\
\text { descriptive methods. }\end{array}$ & $\begin{array}{l}\text { Learning tools based on } \\
\text { discovery learning based } \\
\text { on the concept of } \\
\text { momentum and impulse } \\
\text { are feasible to use. }\end{array}$ \\
\hline $\begin{array}{l}\text { (Ramadoni et al., } \\
\text { 2018) }\end{array}$ & $\begin{array}{l}\text { Research subjects } \\
\text { were students } \\
\text { class X natural } \\
\text { science } 1 \text { MAN } 2 \\
\text { Kota Baru Solok } \\
\text { (i.e. Islamic } \\
\text { School). }\end{array}$ & $\begin{array}{l}\text { Types of Research } \\
\text { Development of } \\
\text { Senior High School } \\
\text { (Islamic School) } \\
\text { science tools with } \\
\text { integrated character } \\
\text { values based on the } \\
\text { discovery learning } \\
\text { model by } \\
\text { approaching science } \\
\text { skills. } \\
\text { Research used } \\
\text { Plomp model } \\
\text { (preliminary } \\
\text { research, } \\
\text { development or } \\
\text { prototyping stage, } \\
\text { and assessment } \\
\text { stage). } \\
\text { The results of the } \\
\text { study were analyzed } \\
\text { using quantitative } \\
\text { descriptive methods. }\end{array}$ & $\begin{array}{l}\text { - Senior High School } \\
\text { science learning tools } \\
\text { integrate character } \\
\text { values based on the } \\
\text { discovery learning } \\
\text { model by approaching } \\
\text { the appropriate science } \\
\text { skills are feasible to use. } \\
\text { - Student learning } \\
\text { outcomes was very good } \\
\text { classical grades and } \\
\text { completeness. }\end{array}$ \\
\hline $\begin{array}{l}\text { (Hikmawati et al., } \\
\text { 2020) }\end{array}$ & $\begin{array}{l}\text { The research } \\
\text { subjects were } 35 \\
\text { students of class } \\
\text { XI natural science } \\
1 \text { of State Senior } \\
\text { High School } 1 \\
\text { Kediri academic } \\
\text { year } 2019 / 2020 \text {. }\end{array}$ & $\begin{array}{l}\text { - The type of research } \\
\text { was pre- } \\
\text { experimental design. } \\
\text { - Using Discovery } \\
\text { Learning Model. } \\
\text { - The research design } \\
\text { was One Group } \\
\text { pretest-posttest } \\
\text { withcontrol grub } \\
\text { design. } \\
\text { The research method } \\
\text { used quantitative } \\
\text { descriptive analysis. }\end{array}$ & $\begin{array}{l}\text { The discovery learning } \\
\text { model is effective in } \\
\text { improving the science } \\
\text { process skills of class XI } \\
\text { students on Elasticity } \\
\text { and Hooke's Law. } \\
\text { - The effectiveness of } \\
\text { discovery learning in } \\
\text { each meeting always } \\
\text { increase. }\end{array}$ \\
\hline (Pursitasari et al., & The research & - The type of research & - Discovery learning can \\
\hline
\end{tabular}




\begin{tabular}{|c|c|c|c|}
\hline $\begin{array}{c}\text { Authors } \\
\text { (years) }\end{array}$ & $\begin{array}{c}\text { Sample } \\
\text { characteristics }\end{array}$ & Research design & The finding \\
\hline 2019) & $\begin{array}{l}\text { subjects were } 31 \\
\text { students grade } \\
\text { VII students of } \\
\text { SMP Negeri } 13 \\
\text { Bogor. }\end{array}$ & $\begin{array}{l}\text { is pre-experimental } \\
\text { design. } \\
\text { - Used the Discovery } \\
\text { Learning Model. } \\
\text { - The research design } \\
\text { used was One } \\
\text { Group pretest- } \\
\text { posttest control grub } \\
\text { design. } \\
\text { The research method } \\
\text { used quantitative } \\
\text { descriptive analysis. }\end{array}$ & $\begin{array}{l}\text { improve students' } \\
\text { scientific literacy. } \\
\text { - Achievement of science } \\
\text { literacy students is } \\
\text { categorized as high and } \\
\text { significant. } \\
\text { - The highest scientific } \\
\text { literacy ability is in } \\
\text { identifying scientific } \\
\text { problems and the lowest } \\
\text { is in explaining scientific } \\
\text { phenomena. }\end{array}$ \\
\hline $\begin{array}{l}\text { (Wicaksono et al., } \\
\text { 2021) }\end{array}$ & $\begin{array}{l}\text { The research } \\
\text { subjects were } 634 \\
\text { documents from } \\
2015 \text { to } 2019\end{array}$ & $\begin{array}{l}\text { The trend research } \\
\text { analyzed was the } \\
\text { discovery learning } \\
\text { model. } \\
\text { - The research method } \\
\text { used bibliometric } \\
\text { analysis based on } \\
\text { Scopus data. }\end{array}$ & $\begin{array}{l}\text { The trend of discovery } \\
\text { learning research started } \\
\text { in 2015, decreased in } \\
\text { 2017, then increased } \\
\text { exponentially in } 2018 \text {. } \\
\text { - Indonesia is the second } \\
\text { largest contributor to } \\
\text { research related to } \\
\text { discovery learning after } \\
\text { the United States. }\end{array}$ \\
\hline $\begin{array}{l}\text { (Kasmiana et al., } \\
\text { 2020) }\end{array}$ & $\begin{array}{l}\text { The research } \\
\text { subjects were all } \\
7 \text { th grade } \\
\text { students of SMP } \\
\text { Negeri } 8 \text { Banda } \\
\text { Aceh academic } \\
\text { year } 2018 / 2019 \text {. }\end{array}$ & $\begin{array}{l}\text { - The type of research } \\
\text { is pre-experimental } \\
\text { design. } \\
\text { - The research used } \\
\text { the Guided } \\
\text { Discovery Learning } \\
\text { Model. } \\
\text { - The research design } \\
\text { used was One } \\
\text { Group pretest- } \\
\text { posttest control grub } \\
\text { design. } \\
\text { The research method } \\
\text { used quantitative } \\
\text { descriptive analysis. }\end{array}$ & $\begin{array}{l}\text { - The guided discovery } \\
\text { model improves student } \\
\text { learning outcomes, } \\
\text { especially in } \\
\text { understanding concepts. } \\
\text { - Student responses } \\
\text { showed more active } \\
\text { during learning. } \\
\text { - Critical thinking skills } \\
\text { have increased. }\end{array}$ \\
\hline $\begin{array}{l}\text { (Khusnul et al., } \\
\text { 2019) }\end{array}$ & $\begin{array}{l}\text { The research } \\
\text { subjects were } \\
\text { students class VII } \\
\text { in } 9 \text { SMP/MTs at } \\
\text { coffee plantations } \\
\text { in Jember } \\
\text { Regency. }\end{array}$ & $\begin{array}{l}\text { - The type of research } \\
\text { was case study. } \\
\text { - The research method } \\
\text { used triangulation } \\
\text { which combines } \\
\text { qualitative and } \\
\text { quantitative } \\
\text { methods. } \\
\text { - Using the discovery } \\
\text { learning model to } \\
\text { measure the science } \\
\text { process. }\end{array}$ & $\begin{array}{l}\text { The pattern of science } \\
\text { skills in discovery } \\
\text { learning can grow and } \\
\text { improve students' } \\
\text { science process skills. } \\
\text { - The learning model } \\
\text { directs students to } \\
\text { actively seek and build } \\
\text { their own knowledge in } \\
\text { the learning process. }\end{array}$ \\
\hline $\begin{array}{l}\text { (Chusni et al., } \\
\text { 2019) }\end{array}$ & $\begin{array}{l}\text { The research } \\
\text { subject was a } \\
\text { document related } \\
\text { to discovery }\end{array}$ & $\begin{array}{l}\text { The method used is } \\
\text { qualitative analysis } \\
\text { with the main } \\
\text { source of literature }\end{array}$ & $\begin{array}{l}\text { The discovery learning } \\
\text { model has potential to } \\
\text { empower critical } \\
\text { thinking skills. }\end{array}$ \\
\hline
\end{tabular}




\begin{tabular}{|c|c|c|c|}
\hline $\begin{array}{c}\text { Authors } \\
\text { (years) }\end{array}$ & $\begin{array}{c}\text { Sample } \\
\text { characteristics }\end{array}$ & Research design & The finding \\
\hline $\begin{array}{l}\text { (Fadlilah et al., } \\
\text { 2020) }\end{array}$ & $\begin{array}{l}\text { The research } \\
\text { subjects were } 48 \\
\text { students of class } \\
\text { XI Senior High } \\
\text { School in Sikka, } \\
\text { East Nusa } \\
\text { Tenggara. }\end{array}$ & $\begin{array}{l}\text { study. } \\
\text { The learning model } \\
\text { studied was } \\
\text { discovery learning } \\
\text { and critical thinking } \\
\text { from Facione. } \\
\text { - The type of research } \\
\text { is pre-experimental } \\
\text { design. } \\
\text { - Using Discovery } \\
\text { Learning Model } \\
\text { with video-based } \\
\text { laboratory-assisted. } \\
\text { The research design } \\
\text { used was One } \\
\text { Group pretest- } \\
\text { posttest control grub } \\
\text { design. } \\
\text { The research method } \\
\text { used quantitative } \\
\text { descriptive analysis. }\end{array}$ & $\begin{array}{l}\text { The discovery learning } \\
\text { model with the help } \\
\text { make students more } \\
\text { actively involved and } \\
\text { constructively obtains } \\
\text { optimal results. } \\
\text { - The video-based } \\
\text { laboratory-assisted } \\
\text { discovery learning } \\
\text { model is more effective } \\
\text { than the conventional } \\
\text { model. } \\
\text { This model can improve } \\
\text { student learning } \\
\text { outcomes. }\end{array}$ \\
\hline (Patandung, 2017) & $\begin{array}{l}\text { The subject of the } \\
\text { research are } \\
\text { students Class V } \\
\text { of SDN } \\
\text { Mannuruki } \\
\text { academic year } \\
2014 / 2015 \text {. }\end{array}$ & $\begin{array}{l}\text { - The type of research } \\
\text { is true experimental } \\
\text { design. } \\
\text { - Using the Discovery } \\
\text { Learning Model. } \\
\text { - The research design } \\
\text { used was One } \\
\text { Group pretest- } \\
\text { posttest control grub } \\
\text { design. } \\
\text { The research method } \\
\text { used descriptive } \\
\text { statistics and } \\
\text { inferential analysis. }\end{array}$ & $\begin{array}{l}\text { The application of the } \\
\text { discovery learning } \\
\text { model which consists of } \\
\text { the observation stage, } \\
\text { problem formulation, } \\
\text { hypothesis for making } \\
\text { stage, data collection } \\
\text { stage, and conclusion } \\
\text { making stage, generally } \\
\text { carried out well. } \\
\text { There is an effect of the } \\
\text { application of the } \\
\text { discovery learning } \\
\text { model on learning } \\
\text { motivation. }\end{array}$ \\
\hline (Setyawati, 2018) & $\begin{array}{l}\text { The research } \\
\text { subjects were } 32 \\
\text { students Class } \\
\text { VIII-D SMP } \\
\text { Negeri Satu Atap } \\
\text { Merosari. }\end{array}$ & $\begin{array}{l}\text { - The type of research } \\
\text { was classroom } \\
\text { action. } \\
\text { - Using the Guided } \\
\text { Discovery Learning } \\
\text { Model. } \\
\text { - The CAR design } \\
\text { used refers to the } \\
\text { Kemmis and } \\
\text { McTaggart models } \\
\text { (planning, action } \\
\text { implementation, } \\
\text { observation, and } \\
\text { reflection stages) }\end{array}$ & $\begin{array}{l}\text { The discovery learning } \\
\text { model can provide a } \\
\text { positive response in the } \\
\text { learning process on the } \\
\text { material structure and } \\
\text { function of plant tissues. } \\
\text { - The discovery model can } \\
\text { improve student } \\
\text { learning outcomes. }\end{array}$ \\
\hline $\begin{array}{l}\text { (Sukmasari \& } \\
\text { Rosana, 2017) }\end{array}$ & $\begin{array}{l}\text { The research } \\
\text { subjects were } 33 \\
\text { Class VIII }\end{array}$ & $\begin{array}{l}\text { Types of Research } \\
\text { Development of } \\
\text { project assessment }\end{array}$ & $\begin{array}{l}\text { - The project assessment } \\
\text { instrument to measure } \\
\text { the problem-solving }\end{array}$ \\
\hline
\end{tabular}




\begin{tabular}{|c|c|c|c|}
\hline $\begin{array}{c}\text { Authors } \\
\text { (years) }\end{array}$ & $\begin{array}{c}\text { Sample } \\
\text { characteristics }\end{array}$ & Research design & The finding \\
\hline & $\begin{array}{l}\text { students of SMP } \\
\text { Muhammadiyah } \\
3 \text { Depok, Sleman } \\
\text { Regency academic } \\
\text { year 2015-2016. }\end{array}$ & $\begin{array}{l}\text { in science learning } \\
\text { to improve the } \\
\text { problem-solving } \\
\text { skills of VIII grade } \\
\text { junior high school } \\
\text { students on the } \\
\text { subject of light and } \\
\text { the human sense of } \\
\text { sight. } \\
\text { The Research was } \\
\text { 4D models, such as } \\
\text { define, design, } \\
\text { develop, } \\
\text { desseminate. } \\
\text { The results of the } \\
\text { study were analyzed } \\
\text { using quantitative } \\
\text { descriptive methods. }\end{array}$ & $\begin{array}{l}\text { skills of science learning } \\
\text { with the discovery } \\
\text { learning model has been } \\
\text { feasible to use. } \\
\text { - There was an increase in } \\
\text { the aspect of problem } \\
\text { solving skills at each } \\
\text { meeting. }\end{array}$ \\
\hline $\begin{array}{l}\text { (Bahari et al., } \\
\text { 2018) }\end{array}$ & $\begin{array}{l}\text { The research } \\
\text { subjects were } 131 \\
\text { Grade V of SD } \\
\text { Cluster V } \\
\text { Blahbatuh } \\
\text { academic year } \\
2016 / 2017 \text {. }\end{array}$ & $\begin{array}{l}\text { - The type of research } \\
\text { is pre-experimental } \\
\text { design. } \\
\text { - Using the Natural } \\
\text { Environment Media- } \\
\text { Assisted Discovery } \\
\text { Learning Model. } \\
\text { - The research design } \\
\text { used was One } \\
\text { Group pretest- } \\
\text { posttest control grub } \\
\text { design. } \\
\text { The research method } \\
\text { uses descriptive and } \\
\text { quantitative } \\
\text { analysis. }\end{array}$ & $\begin{array}{l}\text { The application of the } \\
\text { discovery learning } \\
\text { model assisted by the } \\
\text { media of the natural } \\
\text { environment has an } \\
\text { effect on science learning } \\
\text { outcomes. } \\
\text { - Students become more } \\
\text { active in learning, } \\
\text { making students more } \\
\text { active. }\end{array}$ \\
\hline $\begin{array}{l}\text { (Ariana et al., } \\
2020)\end{array}$ & $\begin{array}{l}\text { The research } \\
\text { subjects were } 30 \\
\text { Class XI students } \\
\text { of State Senior } \\
\text { High School } 1 \\
\text { Bringin academic } \\
\text { year 2018/2019. }\end{array}$ & $\begin{array}{l}\text { - Types of Research } \\
\text { Development of } \\
\text { plant tissue modules } \\
\text { to improve students' } \\
\text { scientific literacy } \\
\text { skills. } \\
\text { - The research uses } \\
\text { the Borg and Gall } \\
\text { model, namely } \\
\text { preliminary study, } \\
\text { planning, module } \\
\text { preparation, expert } \\
\text { assessment, revision, } \\
\text { limited trial, limited } \\
\text { revision. } \\
\text { The results of the } \\
\text { study were analyzed } \\
\text { using quantitative } \\
\text { descriptive methods. }\end{array}$ & $\begin{array}{l}\text { The learning module } \\
\text { based on discovery } \\
\text { learning on plant tissue } \\
\text { material that was } \\
\text { developed meets the } \\
\text { good category so that it } \\
\text { is suitable for use. } \\
\text { - Discovery learning } \\
\text { modules can improve } \\
\text { scientific literacy skills. }\end{array}$ \\
\hline
\end{tabular}




\begin{tabular}{|c|c|c|c|}
\hline $\begin{array}{c}\text { Authors } \\
\text { (years) }\end{array}$ & $\begin{array}{c}\text { Sample } \\
\text { characteristics }\end{array}$ & Research design & The finding \\
\hline $\begin{array}{l}\text { (Yusuf \& Wulan, } \\
\text { 2015) }\end{array}$ & $\begin{array}{l}\text { The research } \\
\text { subjects are } 48 \\
\text { seventh grade } \\
\text { students of SMP } \\
\text { Negeri } 3 \text { Bunyu in } \\
\text { Bulungan } \\
\text { Regency, North } \\
\text { Kalimantan. }\end{array}$ & $\begin{array}{l}\text { - The type of research } \\
\text { is pre-experimental } \\
\text { design. } \\
\text { - Using the Discovery } \\
\text { Learning Model } \\
\text { using Shared and } \\
\text { Webbed Type } \\
\text { learning. } \\
\text { - The research design } \\
\text { used was One } \\
\text { Group pretest- } \\
\text { posttest control grub } \\
\text { design. } \\
\text { The research method } \\
\text { uses descriptive and } \\
\text { quantitative } \\
\text { analysis. }\end{array}$ & $\begin{array}{l}\text { - The application of the } \\
\text { shared and webbed } \\
\text { integrated discovery } \\
\text { learning learning model } \\
\text { can improve students' } \\
\text { science process skills. } \\
\text { - There is no significant } \\
\text { difference in the } \\
\text { improvement of } \\
\text { students' science process } \\
\text { skills between shared or } \\
\text { webbed integration. }\end{array}$ \\
\hline (Dewi et al., 2017) & $\begin{array}{l}\text { The research } \\
\text { subject were } \\
\text { students in the } \\
\text { seventh grade of } \\
\text { SMP Negeri } 3 \\
\text { Ngronggot } \\
\text { Nganjuk. }\end{array}$ & $\begin{array}{l}\text { - The type of research } \\
\text { is classroom action. } \\
\text { - Using the Guided } \\
\text { Discovery Learning } \\
\text { Model. } \\
\text { - The CAR design } \\
\text { used was carried out } \\
\text { in two cycles, each } \\
\text { cycle consisting of } \\
\text { the action planning } \\
\text { stage, action } \\
\text { implementation, } \\
\text { observation, and } \\
\text { reflection. }\end{array}$ & $\begin{array}{l}\text { The use of Discovery } \\
\text { learning on the topic of } \\
\text { population density on } \\
\text { the environment can } \\
\text { improve students' } \\
\text { scientific literacy skills. }\end{array}$ \\
\hline (Hadi et al., 2020) & $\begin{array}{l}\text { The research } \\
\text { subjects were } 27 \\
\text { Class of VII } \\
\text { students in SMP } \\
\text { Negeri } 1 \text { Labang } \\
\text { Bangkalan. }\end{array}$ & $\begin{array}{l}\text { - The type of research } \\
\text { is pre-experimental } \\
\text { design. } \\
\text { - Using the Discovery } \\
\text { Learning Model } \\
\text { with an } \\
\text { Ethnoscience } \\
\text { approach. } \\
\text { - The research design } \\
\text { used is a quasi- } \\
\text { experimental design } \\
\text { with a one shot case } \\
\text { study. } \\
\text { The research method } \\
\text { used quantitative } \\
\text { descriptive analysis. }\end{array}$ & $\begin{array}{l}\text { The discovery learning } \\
\text { model with an } \\
\text { ethnoscience approach } \\
\text { can improve students' } \\
\text { science literacy. } \\
\text { - Discovery learning with } \\
\text { an ethnoscience } \\
\text { approach is positively } \\
\text { correlated with the } \\
\text { process of solving } \\
\text { questions for students, } \\
\text { the ability to write } \\
\text { opinions in connecting } \\
\text { concepts with facts } \\
\text { found in everyday life. }\end{array}$ \\
\hline $\begin{array}{l}\text { (Ceriasari et al., } \\
\text { 2019) }\end{array}$ & $\begin{array}{l}\text { The research } \\
\text { subjects were } \\
\text { Class VII A and } \\
\text { VII D of SMP } \\
\text { Negeri } 15 \\
\text { Pesawaran }\end{array}$ & $\begin{array}{l}\text { The type of research } \\
\text { was pre- } \\
\text { experimental design. } \\
\text { - Using LKS Model } \\
\text { Discovery Learning. } \\
\text { - The research design }\end{array}$ & $\begin{array}{l}\text { Discovery learning- } \\
\text { based worksheets } \\
\text { succeeded for increasing } \\
\text { the mastery of students' } \\
\text { concepts in the high } \\
\text { category. }\end{array}$ \\
\hline
\end{tabular}




\begin{tabular}{|c|c|c|c|}
\hline $\begin{array}{l}\text { Authors } \\
\text { (years) }\end{array}$ & $\begin{array}{c}\text { Sample } \\
\text { characteristics }\end{array}$ & Research design & The finding \\
\hline $\begin{array}{l}\text { (Chusni et al., } \\
\text { 2021) }\end{array}$ & $\begin{array}{l}\text { The research } \\
\text { subjects were } 67 \\
\text { students of class } \\
\text { VII SMP in } \\
\text { Sleman Regency. }\end{array}$ & $\begin{array}{l}\text { used was One } \\
\text { Group pretest- } \\
\text { posttest control grub } \\
\text { design. } \\
\text { The research method } \\
\text { used descriptive and } \\
\text { quantitative } \\
\text { analysis. } \\
\text { The type of research } \\
\text { is pre-experimental } \\
\text { design. } \\
\text { - Using LKS Model } \\
\text { Discovery Learning. } \\
\text { The research design } \\
\text { used was One } \\
\text { Group pretest- } \\
\text { posttest control grub } \\
\text { design. } \\
\text { The research method } \\
\text { used descriptive and } \\
\text { quantitative } \\
\text { analysis. }\end{array}$ & $\begin{array}{l}\text { - Learning by Discovery } \\
\text { learning model using E- } \\
\text { Learning makes students } \\
\text { learn actively, } \\
\text { independently, and } \\
\text { enthusiastically looking } \\
\text { for various sources. } \\
\text { - The critical thinking } \\
\text { ability of students in } \\
\text { junior high school, } \\
\text { especially on } \\
\text { environmental change } \\
\text { material, is still low. }\end{array}$ \\
\hline $\begin{array}{l}\text { (Khairuna et al., } \\
\text { 2021) }\end{array}$ & $\begin{array}{l}\text { The research } \\
\text { subjects were } \\
\text { Class XI IPA } \\
\text { MAN } 1 \text { Aceh } \\
\text { Besar District and } \\
\text { MAS Oemar } \\
\text { Diyan Aceh Besar } \\
\text { District. }\end{array}$ & $\begin{array}{l}\text { - The type of research } \\
\text { is pre-experimental } \\
\text { design. } \\
\text { - Using the Discovery } \\
\text { Learning Model } \\
\text { assisted by a virtual } \\
\text { laboratory. } \\
\text { - The research design } \\
\text { used was One } \\
\text { Group pretest- } \\
\text { posttest control grub } \\
\text { design. } \\
\text { The research method } \\
\text { uses descriptive and } \\
\text { quantitative } \\
\text { analysis. }\end{array}$ & $\begin{array}{l}\text { - Discovery learning has } \\
\text { an effect on science } \\
\text { process skills and } \\
\text { student learning } \\
\text { outcomes. } \\
\text { - Science process skills } \\
\text { and student learning } \\
\text { outcomes have a positive } \\
\text { relationship. }\end{array}$ \\
\hline $\begin{array}{l}\text { (Winarni et al., } \\
\text { 2020) }\end{array}$ & $\begin{array}{l}\text { The research } \\
\text { subjects were } 36 \\
\text { of } 4^{\text {th }} \text { grade } \\
\text { students at SDN } \\
\text { Bengkulu Tengah, } \\
\text { Bengkulu } \\
\text { Province for the } \\
\text { academic year } \\
\text { 2017-2018. }\end{array}$ & $\begin{array}{l}\text { - The type of research } \\
\text { was pre- } \\
\text { experimental design. } \\
\text { - Using the Discovery } \\
\text { Learning Model } \\
\text { with ICT media. } \\
\text { - The research design } \\
\text { used was One } \\
\text { Group pretest- } \\
\text { posttest control grub } \\
\text { design. } \\
\text { The research method } \\
\text { used descriptive and } \\
\text { quantitative } \\
\text { analysis. }\end{array}$ & $\begin{array}{l}\text { Discovery learning with } \\
\text { ICT media can improve } \\
\text { students' scientific and } \\
\text { language literacy skills } \\
\text { than conventional } \\
\text { learning. }\end{array}$ \\
\hline
\end{tabular}




\begin{tabular}{|c|c|c|c|}
\hline $\begin{array}{l}\text { Authors } \\
\text { (years) }\end{array}$ & $\begin{array}{c}\text { Sample } \\
\text { characteristics }\end{array}$ & Research design & The finding \\
\hline $\begin{array}{l}\text { (Mustikaningrum } \\
\text { et al., 2021) }\end{array}$ & $\begin{array}{l}\text { The research } \\
\text { subjects were } 15 \\
\text { of } 4^{\text {th }} \text { grade } \\
\text { students at SDN } 2 \\
\text { Limbangan, } \\
\text { Kendal. }\end{array}$ & $\begin{array}{l}\text { - The type of research } \\
\text { was classroom } \\
\text { action. } \\
\text { - Using the Discovery } \\
\text { Learning Model } \\
\text { assisted by google } \\
\text { meet application. } \\
\text { - The CAR design } \\
\text { used was carried out } \\
\text { in two cycles, each } \\
\text { cycle consisting of } \\
\text { action stage, the } \\
\text { action planning } \\
\text { stage, the action. } \\
\text { Observation and } \\
\text { reflection. }\end{array}$ & $\begin{array}{l}\text { - Learning with the } \\
\text { discovey learning model } \\
\text { assisted by Google Meet } \\
\text { application can improve } \\
\text { critical thinking skills } \\
\text { and science learning } \\
\text { outcomes. } \\
\text { - Students learn to be } \\
\text { more independent, } \\
\text { active, and creative. }\end{array}$ \\
\hline $\begin{array}{l}\text { (Arianda et al., } \\
\text { 2018) }\end{array}$ & $\begin{array}{l}\text { The research } \\
\text { subject were } 7^{\text {th }} \\
\text { grade studens at } \\
\text { SMPN } 1 \text { Kampar } \\
\text { Timur academic } \\
\text { year } 2017 / 2018 \text {. }\end{array}$ & $\begin{array}{l}\text { - The type of research } \\
\text { was pre- } \\
\text { experimental design. } \\
\text { - Using the Discovery } \\
\text { Learning Model } \\
\text { with scientific } \\
\text { literacy nuances. } \\
\text { - The research design } \\
\text { used was One } \\
\text { Group pretest- } \\
\text { posttest control grub } \\
\text { design. } \\
\text { The research method } \\
\text { uses descriptive and } \\
\text { quantitative } \\
\text { analysis. }\end{array}$ & $\begin{array}{l}\text { The discovery learning } \\
\text { model with scientific } \\
\text { literacy nuances has a } \\
\text { significant influence on } \\
\text { students' cognitive, } \\
\text { affective, and } \\
\text { psychomotor domains. }\end{array}$ \\
\hline $\begin{array}{l}\text { (Yerimadesi et al., } \\
\text { 2021). }\end{array}$ & $\begin{array}{l}\text { The research } \\
\text { subjects were } 30 \\
\text { students of State } \\
\text { Senior High } \\
\text { School } 9 \text { Padang. }\end{array}$ & $\begin{array}{l}\text { - Types of Research } \\
\text { Development of } \\
\text { Acid-Base Module } \\
\text { based on guided } \\
\text { discovery learning. } \\
\text { - Research using 4D } \\
\text { models, namely } \\
\text { define, design, } \\
\text { develop, } \\
\text { desseminate. } \\
\text { The results of the } \\
\text { study were analyzed } \\
\text { using quantitative } \\
\text { descriptive methods. }\end{array}$ & $\begin{array}{l}\text { The developed guided } \\
\text { discovery learning-based } \\
\text { Acid-Base module is } \\
\text { valid and practical. } \\
\text { - The Acid-Base module } \\
\text { based on guided } \\
\text { discovery learning can } \\
\text { improve student } \\
\text { learning outcomes. }\end{array}$ \\
\hline $\begin{array}{l}\text { (Sunarsih et al., } \\
\text { 2020) }\end{array}$ & $\begin{array}{l}\text { The research } \\
\text { subjects were } 63 \\
\text { of } 10^{\text {th }} \text { grade } \\
\text { science students } \\
\text { of State Senior } \\
\text { High School } 1 \\
\text { Kertek }\end{array}$ & $\begin{array}{l}\text { Types of Research } \\
\text { Development of the } \\
\text { Biodiversity Module } \\
\text { based on discovery } \\
\text { learning. } \\
\text { - The research phase } \\
\text { was problem }\end{array}$ & $\begin{array}{l}\text { The development of the } \\
\text { Biodiversity module } \\
\text { using local-based } \\
\text { discovery learning, the } \\
\text { potential of Wonosobo, } \\
\text { is quite feasible and } \\
\text { effective to use. }\end{array}$ \\
\hline
\end{tabular}




\begin{tabular}{|c|c|c|c|}
\hline $\begin{array}{c}\text { Authors } \\
\text { (years) }\end{array}$ & $\begin{array}{c}\text { Sample } \\
\text { characteristics }\end{array}$ & Research design & The finding \\
\hline $\begin{array}{l}\text { (Purwaningsih et } \\
\text { al., 2020) }\end{array}$ & $\begin{array}{l}\text { The research } \\
\text { subjects were } 53 \\
\text { of } 10^{\text {th }} \text { grade } \\
\text { students of all } \\
\text { Senior High } \\
\text { School in Malang. }\end{array}$ & $\begin{array}{l}\text { analysis, } \\
\text { development, and } \\
\text { experimentation. } \\
\text { - The results of the } \\
\text { study were analyzed } \\
\text { using quantitative } \\
\text { descriptive methods. } \\
\text { - The type of research } \\
\text { was pre- } \\
\text { experimental design. } \\
\text { - Using STEM-PjBL } \\
\text { and Discovery } \\
\text { Learning } \\
\text { The research design } \\
\text { used was One } \\
\text { Group pretest- } \\
\text { posttest control grub } \\
\text { design. } \\
\text { The research method } \\
\text { used descriptive and } \\
\text { quantitative } \\
\text { analysis. }\end{array}$ & $\begin{array}{l}\text { The problem solving } \\
\text { scores of students who } \\
\text { studied with STEM PjBL } \\
\text { experienced a significant } \\
\text { increase compared to } \\
\text { students who studied } \\
\text { with the Discovery } \\
\text { learning model. } \\
\text { - The use of technology } \\
\text { can increase the } \\
\text { effectiveness and } \\
\text { efficiency of learning. }\end{array}$ \\
\hline $\begin{array}{l}\text { (Ardianto \& } \\
\text { Rubini, 2016) }\end{array}$ & $\begin{array}{l}\text { The research } \\
\text { subjects were } 70 \\
\text { of } 8^{\text {th }} \text { grade } \\
\text { Students in } \\
\text { Bandung City, }\end{array}$ & $\begin{array}{l}\text { - The type of research } \\
\text { was pre- } \\
\text { experimental design. } \\
\text { - Using Guided } \\
\text { Discovery Learning } \\
\text { and PBL } \\
\text { - The research design } \\
\text { used was One } \\
\text { Group pretest- } \\
\text { posttest control grub } \\
\text { design. } \\
\text { The research method } \\
\text { used descriptive and } \\
\text { quantitative } \\
\text { analysis. }\end{array}$ & $\begin{array}{l}\text { - Guided discovery } \\
\text { learning and PBL can } \\
\text { improve scientific } \\
\text { literacy and student } \\
\text { learning outcomes. }\end{array}$ \\
\hline $\begin{array}{l}\text { (Rubini et al., } \\
\text { 2017) }\end{array}$ & $\begin{array}{l}\text { The research } \\
\text { subjects were } 70 \\
\text { of seventh grade } \\
\text { students in Bogor, } \\
\text { West Java. }\end{array}$ & $\begin{array}{l}\text { - The type of research } \\
\text { was pre- } \\
\text { experimental design. } \\
\text { - Using laboratory- } \\
\text { based Discovery } \\
\text { Learning. } \\
\text { - The research design } \\
\text { used was One } \\
\text { Group pretest- } \\
\text { posttest control grub } \\
\text { design. } \\
\text { The research method } \\
\text { used descriptive and } \\
\text { quantitative } \\
\text { analysis. }\end{array}$ & $\begin{array}{l}\text { Laboratory-based } \\
\text { discovery learning } \\
\text { effectively improves } \\
\text { student literacy because } \\
\text { it provides students with } \\
\text { opportunities to engage } \\
\text { in hands-on activities } \\
\text { that encourage } \\
\text { meaningful learning and } \\
\text { discussion. }\end{array}$ \\
\hline (Laila \& Firaina, & The research & - The type of research & - Based on education \\
\hline
\end{tabular}




\begin{tabular}{|c|c|c|c|}
\hline $\begin{array}{c}\text { Authors } \\
\text { (years) }\end{array}$ & $\begin{array}{c}\text { Sample } \\
\text { characteristics }\end{array}$ & Research design & The finding \\
\hline 2019) & $\begin{array}{l}\text { subjects were } 10 \\
\text { research journals. }\end{array}$ & $\begin{array}{l}\text { was meta-analysis } \\
\text { journal related to the } \\
\text { Discovery learning } \\
\text { model on students' } \\
\text { scientific literacy. } \\
\text { - The research method } \\
\text { used descriptive and } \\
\text { quantitative } \\
\text { analysis. }\end{array}$ & $\begin{array}{l}\text { level, the effect of } \\
\text { discovery learning } \\
\text { model on high school } \\
\text { students is greater than } \\
\text { on junior high school } \\
\text { students. } \\
\text { - Based on the subject } \\
\text { matter, the effect of the } \\
\text { discovery learning } \\
\text { model on ecosystem } \\
\text { materials is more } \\
\text { influential than global } \\
\text { warming, temperature } \\
\text { and heat, static fluids. }\end{array}$ \\
\hline
\end{tabular}

\section{Characteristics of the Discovery Learning Model}

The characteristics of discovery learning are: (1) Students learn like a scientist, which is exploring a problem and finding answers from the results of the experiment, (2) Students carrying out identification activities, hypotheses, designing experiments to collect data, comparing, analyzing, drawing conclusions, and reflecting, and (3) the teacher's role is as a facilitator, which is plays a role in designing learning. Based on these characteristics, the discovery learning model can support learning in the 21st century. It was from the teaching paradigm to the learning paradigm. It means that teacher-centered learning must be transformed into learner-centered learning. The vision of 21st century education are: (1) learning for thinking is oriented to logical and rational knowledge, (2) learning is oriented to problem solving, (3) independent learning is oriented to character building, and (4) learning to live together is oriented to tolerance. and ready to work together (Winarni et al., 2020).

The discovery learning model has five syntaxes, such as orientation, hypothesis generation, hypothesis testing, conclusions, and regulation (Serefina \& Luthfi, 2020). At the orientation stage students are asked to identify problems with their prior knowledge, this is one way to encourage students' curiosity. At the hypothesis stage, students are asked to hypothesize a problem that has been formulated, this stage teaches students about the delivery of ideas from their knowledge, understanding, or experience. At the hypothesis testing stage, the student's activities are to find answers of the problems that have been formulated, at this stage students design experiments, take data, and then analyze. At the conclusion stage, students are asked to conclude from the hypothesis testing stage, at this stage students are asked to compare the hypothesis stage with the hypothesis testing stage whether there is a difference. At the regulatory stage, which includes planning, monitoring, and evaluation, at this stage you are asked to reflect on whether all stages have been carried out in accordance with the ideal stages.

\section{Research Trends}

The discovery learning model is one of the learning models developed in elementary schools to high schools for science material. One of the discovery learning studies in elementary schools was carried out by Winarni et al. (2020) at SDN Bengkulu Tengah 
with the aim of knowing the effect of discovery learning using ICT on the topic of bamboo conservation on students' language and scientific literacy. Furthermore, one of the discovery learning studies in secondary schools was carried out by Pursitasari et al. (2019) at the State Junior High School 13 Bogor is aimed to increase scientific literacy through discovery learning on the theme of material characteristics.

Discovery learning models can be used with the help of: guided discovery learning, Guided Discovery Learning-Argument Mapping (GDL-AM), online-based discovery learning, video-based laboratory-assisted discovery learning models, real objectassisted discovery learning models, and assisted discovery learning models. natural environmental media. Based on research conducted by Ristanto et al. (2021) used a guided discovery learning model assisted by argument mapping (GDL-AM) with the aim of improving students' critical thinking skills on environmental change material and the result there was an increase in student's critical thinking skills. In addition, during the study period at home due to the covid-19 pandemic, discovery learning also can be done online. The results of critical thinking research and science learning outcomes through the application of discovery learning models used Google Meet application can be increased (Mustikaningrum et al., 2021). In addition, E-Learning learning through the discovery learning model makes students active, independent, and enthusiastic in seeking various sources (Chusni et al., 2021). The types of discovery learning model research include development research, literature review research, preexperimental design, case studies, and classroom action research. The trend of discovery learning research began in 2015, decreased in 2017, then increased exponentially in 2018. Indonesia is the second largest contributor to research related to discovery learning after the United States (Wicaksono et al., 2021).

\section{Advantages of the Discovery Learning Model}

One of the advantages of discovery learning is; it can increase students' scientific literacy. After students' literacy increases, it is expected that student learning outcomes will also increase. Based on research conducted by Pursitasari et al. (2019), it aims to improve scientific literacy through discovery learning on the theme of material characteristics. The results showed an increase in scientific literacy in the high category, discovery learning encouraged students to construct and create a relationship between their knowledge and an application in everyday life. In addition, the highest scientific literacy ability was in the aspect of identifying scientific problems and the lowest in explaining phenomena. scientific. In line with that, according to Ardianto \& Rubini (2016), guided discovery learning and PBL can improve scientific literacy and student learning outcomes.

Learning with the discovery learning model can train students' science process skills. Discovery learning can improve students' science process skills on the indicators of planning experiments, because learning can stimulate students to develop their own curiosity (Yusuf \& Wulan, 2015). The discovery learning model is an important component in the constructivist approach, for students to find their own concepts and provide pleasure when they find them (Hikmawati et al, 2021). The advantages of the discovery learning model are: (1) Motivating students during search and discovery steps, (2) Helping students systematize their own ideas, (3) Potential to improve student performance during the learning process, (4) Increase curiosity and interest in learning a subject. materials, (5) Empower students' critical thinking skills, (6) Improve students' 
science process skills, (7) Improve students' scientific literacy, (8) Make students more daring to ask questions and express opinions, (9) Improve aspects of problem solving skills, (10) Improve students' understanding of concepts, and (11) Improve student learning outcomes.

\section{Disadvantages of the Discovery Learning Model}

Despite many advantages, the discovery learning model also has several disadvantages, such as (1) In general, the discovery learning model does not provide maximum impact without the use of assistance, (2) Students also experience confusion if they are not given instructions at the discovery stage, and (3) Requires too much preparation and study time. Discovery learning is maximized when combined with other models, methods, or learning media. The influence of the unaided discovery learning model does not seem to run optimally, while the assisted discovery learning model makes students more actively involved and constructively shows optimal results (Chusni et al., 2021).

\section{Suggestions for Discovery Learning Model Implementation}

The suggestions that can be given based on the literature review of this discovery learning model are that the teacher should explain the learning steps that will be carried out to students so that the learning process can run well and improve students' science process skills in a whole. In the application of the discovery learning model, it should be done seriously and according to procedures and the preparation of teachers and students to obtain optimal results; the school should be able to accommodate and facilitate for optimizing the implementation of discovery learning; the government can make efforts in providing facilities and facilities for learning science school. Teachers should consider the use of the environment as a medium that supports learning (Bahari et al., 2018).

\section{CONCLUSIONS}

Based on the literature review of the implementation of the discovery learning model in 2012-2021 that has been carried out, it can be concluded that the discovery learning model has a positive impact on science learning. The application of the discovery learning model can improve students' critical thinking skills, improve students' science process skills, improve students' scientific literacy, improve aspects of problem solving skills, improve students' conceptual understanding, and improve student learning outcomes. In addition to having the advantages of the discovery learning model, it has several disadvantages, including being more optimal when it is assisted with media or other methods, students will be confuse if there is no instruction from the teacher, and require a lot of preparation and learning time. The limitation of this research is that it is limited to 30 journal articles analyzed. In addition, the limitation of the research analyzed from elementary to middle school levels cannot focus on each level of education. Recommendations for further research are that the quantity and quality of the analyzed journal levels need to be improved. In addition, journal studies related to discovery learning need to be focused on each level of education. 


\section{REFERENCES}

Ariana, D., Situmorang, R. P., \& Krave, A. S. (2020). Pengembangan modul berbasis discovery learning pada materi jaringan tumbuhan untuk meningkatkan kemampuan literasi sains siswa kelas xi ipa sma. Jurnal Pendidikan Matemaika dan IPA, 11(1), 34-46. https://doi.org/10.26418/jpmipa.v11i1.31381

Ardianto, D., \& Rubini, B. (2016). Comparison of students' scientific literacy in integrated science learning through model of guided discovery and problem based learning. Jurnal Pendidikan IPA Indonesia, 5(1), 31-37. https://doi.org/10.15294/jpii.v5i1.5786

Arianda, N., Anhar, A., \& Syamsurizal. (2018). The effects of discovery learning model nuanced science literacy towards students' competence in learning natural science. International Journal of Progressive Science and Technologies, 8(1), 96-105. http://dx.doi.org/10.52155/ijpsat.v8.1.396

Bahari, N. K. I., Darsana, I. W., \& Putra, S. (2018). Pengaruh model discovery learning berbanuan media lingkungan alam sekitar terhadap hasil belajar ipa. Jurnal Ilmiah Sekolah Dasar, 2(2), 103-112. https:/ / doi.org/10.23887/jisd.v2i2.15488

Ceriasari, B., Sunyono, \& Rudibyani, R. B. (2019). Implementation of discovery learning based worksheet to improve students concept mastery of science. Jurnal Pendidikan MIPA, 20(1), 7-11. https://doi.org/10.23960/jpmipa/v20i1.pp7-11

Chusni, M. M., Saputro, S., Suranto, \& Rahardjo, S. B. (2019). The potential of discovery learning models to empower students critical thinking skills. Journal of Physics: Conf. Series, 1464(012036), 1-7. https:/ / doi.org/10.1088/1742-6596/1464/1/012036

Chusni, M. M., Saputro, S., \& Suranto. (2021). Student's critical thinking skills through discovery learning model using e-learning on environmental change subject matter. European Journal of Educational Research, 10(3), 1123-1135. https://doi.org/10.12973/eujer.10.3.1123

Dewi, S. R., Nurmilawati, M., \& Budiretnani, D. A. (2017). Improving of scientific literacy ability using discovery learning model at the seventh grade students of state jhs 3 Ngronggot, Nganjuk-Indonesia. Jurnal Pendidikan Biologi Indonesia, 3(3), 266-271. https://doi.org/10.22219/jpbi.v3i3.4597

Fadlilah, N., Sulisworo, D., \& Maruto, G. (2020). The effectiveness of a video-based laboratory on discovery learning to enhance learning outcomes. Universal Journal of Educational Research, 8(8), 3648-3654. https:// doi.org/10.13189/ujer.2020.080843

Hadi, W. P., Munawaroh, F., Rosidi, F., \& Wardani, W. K. (2020). Penerapan model discovery learning berpendekatan etnosains untuk mengetahui profil literasi sains siswa smp. Jurnal IPA dan Pembelajaran IPA, 4(2), 178-192. https:/ / doi.org/10.24815/jipi.v4i2.15771

Hikmawati, H., Kosim, K., Doyan, A., Gunawan, G., \& Kurniwan, E. (2020). Discovery learning model to practise student' science process skill in elasticity and hooke's law. Journal of Physics: Conf. Series, 1779(012087), 1-7. https://doi.org/10.1088/1742-6596/1779/1/012087

Ibnu, S., Mukadis, A., \& Dasna, W. (2003). Dasar-dasar metodologi penelitian. Malang: Lemlit UM.

Kasmiana, Yusrizal, \& Syukri, M. (2020). The application of guided discovery learning model to improve students concepts understanding. Journal of Physics: Conf. Series, 1460(012122), 16. https://doi.org/10.1088/1742-6596/1460/1/012122

Khairuna, Rahmatan, H., Sarong, M. A., Supriatno, \& Pada, A. U. T. (2021). Penerapan model discovery learning dengan pemanfaatan virtual laboratory untuk meningkatkan keterampilan proses sains dan hasil belajar peserta didik pada materi sistem ekskresi. Jurnal Pendidikan Sains Indonesia, 9(2), 280-292. https://doi.org/10.24815/jpsi.v9i2.18875

Khusnul, K., Suratno, \& Yushardi. (2019). The pattern of skills of science process in discovery learning: a case study of science learning in coffee plantation school. Journal of Physics: Conf. Series, 1211(012105), 1-5. https://doi.org/10.1088/1742-6596/1211/1/012105

Kusumastuti, A. \& Khoiron, A. M. (2019). Metode penelitian kualitatif. Semarang: LPSP. 
Laila, R., \& Firaina, R. (2019). Meta analisis pengaruh model discovery learning terhadap literasi sains siswa. Jurnal Penelitian dan Pembelajaran Fisika, 6(2), 120-127. https://doi.org/10.24036/jppf.v6i2.108662

Mustikaningrum, G., Widyanto, \& Mediatati, N. (2021). Application of the discovery learning model assisted by google meet to improve student' critical thinking skills and science learning outcomes. International Journal of Elementary Education, 5(1), 30-38. https://doi.org/10.23887/ijee.v5i1.34344

Patandung, Y. (2017). Pengaruh model discovery learning terhadap peningkatan motivasi belajar ipa siswa. Journal of Educational Science and Technologi, 3(1), 9-17. https:// doi.org/10.26858/est.v3i1.3508

Pursitasari, I., D., Suhardi, E., \& Sunarti, T. (2019). Promoting science literacy with discovery learning. Journal of Physics: Conf. Series, 1233(012074), 1-6. https://doi.org/10.1088/17426596/1233/1/012074

Purwaningsih, E., Sari, S. P., Sari, A. M., \& Suryadi. (2020). The effect of STEM-PjBL and discovery learning on improving students' problem solving skills of the impulse and momentum topic. Jurnal Pendidikan IPA Indonesia, 9(4), 465-476. https://doi.org/10.15294/jpii.v9i4.26432

Ramadoni, A., Yulkifli, \& Ratnawulan. (2018). Development of physic module sma/ma integrated character values based on discovery learning models with approach science process skills. Journal of Physics: Conf. Series, 1185(012068), 1-6. https://doi.org/10.1088/1742-6596/1185/1/012068

Ristanto, R. H., Ahmad, A. S., \& Komala, R. (2021). Critical thinking of environmental changes: A biological instruction using guided learning-argument mapping (GDL-AM). $\begin{array}{llll}\text { Participatory Educaional } \quad \text { Research } & \text { (PER), }\end{array}$ http://dx.doi.org/10.17275/per.22.10.9.1

Rubini, B., Pursitasari, I., D., Ardianto, D., \& Nugraha, H. (2017). Improving students' scientific literacy on environmental pollution topics through laboratory-based discovery learning. Jurnal Pengajaran MIPA, 22(2), 1-6. https://doi.org/10.18269/jpmipa.v22i2.8459

Safaruddin, S., Degeng, I., Setyosari, P., \& Murtadho, N. (2020). The Effect of PjBL with WBL Media and Cognitive Style on Studentsâ€ $€^{\mathrm{TM}}$ Understanding and Science-Integrated Concept Application. Jurnal Pendidikan IPA Indonesia, 9(3), 384-395. doi:https://doi.org/10.15294/jpii.v9i3.24628

Serefina, V., \& Luthfi, K. (2021). Development of discovey learning-based on online learning tools on momentum and impulse. Journal of Physics: Conf. Series, 1876(012076), 1-5. https:/ / doi.org/10.1088/1742-6596/1876/1/012076

Setyawati, E. (2018). Upaya peningkatan hasil belajar ipa melalui model pembelajaran discovery learning pada peserta didik. Ilmu Pendidikan: Jurnal Kajian Teori dan Praktik Kependidikan, 3(1), 50-59. https://doi.org/10.17977/um027v3i12018p050

Sugiarto, E. (2015). Menyusun proposal penlitian kualitatif: Skripsi dan tesis. Suaka Media.

Sukmasari, V. P., \& Rosana, D. (2017). Pengembangan penilaian proyek pembelajaran ipa berbasis discovery learning untuk mengukur keterampilan pemecahan masalah. Jurnal Inovasi Pendidikan IPA, 3(1), 101-110. https:// doi.org/10.21831/jipi.v3i1.10468

Sunarsih, S., Rahayuningsih, M., \& Setiati, N. (2020). The development of biodiversity module using discovery learning based on local potencial of Wonosobo. Journal of Innovative Science Education, 9(1), 1-11. https://doi.org/10.15294/jise.v8i1.31178

Wicaksono, A. G., Sunarno, W., Ashadi, \& Prayitno, B. A. (2021). Research trends of discovery learning from 2015-2019: A bibilometric analysis. Journal of Physics: Conf. Series, 1842(012026), 1-6. https://doi.org/10.1088/1742-6596/1842/1/012026

Winarni, E, W., Hambali, D., \& Purwandari. E. P. (2020). Analysis of language and scientific literacy skills for 4 th grade elementary school student through discovery learning and ict 


$\begin{array}{llll}\text { media. International Jounal of Instruction, 13(2), 213-222. } & \end{array}$
https://doi.org/10.29333/iji.2020.13215a

Yerimadesi, Bayharti, Jannah, S. M., Lufri, Festiyed, \& Kiram. Y. (2021). Validity and practitality of acid-base module based on guided discovery learning for senior high school. IOP Conference Series: Materials Science and Engineering, 335(012097), 1-12. https:// doi.org/10.1088/1757-899X/335/1/012097

Yusuf, M., \& Wulan, A. R. (2015). Penerapan model pembelajaran discovery learning menggunakan pembelajaran tipe shared dan webbed untuk meningkatkan keterampilan proses sains. Jurnal Penelitian \& Pengembangan Pendidikan Fisika, 1(2), 19-26. https://doi.org/10.21009/1.01204

\footnotetext{
${ }^{*}$ Mahyuddin Syaifuloh, S.Pd. (Corresponding Author)

Department postgraduate of Science,

State University of Surabaya,

Kampus Lidah Gedung CPD, Jalan Kampus L,UNESA, 60213, Indonesia

Email: mahyuddin.19021@mhs.unesa.ac.id

Dr. Sifak Indana, M.Pd.

Department postgraduaste of Science,

State University of Surabaya,

Kampus Lidah Gedung CPD, Jalan Kampus L,UNESA, 60213, Indonesia

Email: sifakindana@unesa.ac.id

Prof. Dr. Hj. Rudiana Agustini, M.Pd.

Department postgraduate of Science,

State University of Surabaya,

Kampus Lidah Gedung CPD, Jalan Kampus L,UNESA, 60213, Indonesia

Email: rudianaagustini@unesa.ac.id
} 